12 | 1990

Varia

\title{
L'histoire du brochet et de la grenouille
}

Pascal et Izaac Walton

Antony McKenna

\section{(2) OpenEdition}

Journals

Édition électronique

URL : http://journals.openedition.org/ccibp/637

DOI : $10.4000 /$ ccibp. 637

ISSN : 2493-7460

Éditeur

Centre international Blaise Pascal

Édition imprimée

Date de publication : 4 janvier 1990

Pagination : 18-19

ISSN : 0249-6674

Référence électronique

Antony McKenna, "L'histoire du brochet et de la grenouille », Courrier du Centre international Blaise Pascal [En ligne], 12 | 1990, mis en ligne le 08 janvier 2016, consulté le 19 avril 2019. URL : http:// journals.openedition.org/ccibp/637; DOI : 10.4000/ccibp.637

Ce document a été généré automatiquement le 19 avril 2019

Centre international Blaise Pascal 


\title{
L'histoire du brochet et de la grenouille
}

\author{
Pascal et Izaac Walton
}

Antony McKenna

L'histoire du brochet et de la grenouille de Liancourt. Ils le font toujours et jamais autrement, ni autre chose d'esprit (Lafuma 738).

1 Ce fragment de Pascal est resté assez obscur jusqu'à la découverte par Ernest Jovy ${ }^{1}$ de l'anecdote concernant un brochet et une grenouille. Il s'avérait alors que le duc de Liancourt avait exploité cette anecdote comme un argument contre l'automatisme animal, et que Pascal esquissait une réfutation de cet argument. Le contexte de ce débat est indiqué par Fontaine dans un passage pittoresque de ses Mémoires :

Mais puis-je oublier le plaisant entretien où ce bon seigneur ferma la bouche à $\mathrm{M}$. Arnauld, tout savant qu'il était? On parlait de la philosophie de M. Descartes qui était alors l'entretien de toutes les compagnies. M. Arnauld, qui avait un esprit universel et qui était entré dans le système de Descartes sur les bêtes, soutenait que ce n'était que des horloges, et que, quand elles criaient, ce n'était qu'une roue d'horloge qui faisait du bruit. M. de Liancourt lui dit: «J'ai là-bas deux chiens qui tournent la broche chacun leur jour. L'un s'en trouvant embarrassé, se cacha lorsqu'on l'allait prendre, et on eut recours à son camarade pour tourner au lieu de lui. Le camarade cria, et fit signe de sa queue qu'on le suivît. Il alla dénicher l'autre dans le grenier et le houspilla. Sont-ce là des horloges? » dit-il à M. Arnauld qui trouva cela si plaisant qu'il ne put faire autre chose que d'en rire ${ }^{2}$.

Dessin extrait de The complete Angler.

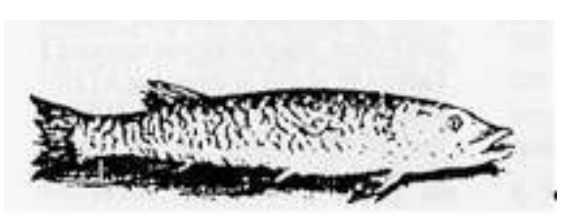

2 Ensemble, ces passages semblent confirmer la remarque de Marguerite Périer selon laquelle Pascal était favorable à la théorie cartésienne des animaux-machines ${ }^{3}$. 
3 En ce qui concerne l'anecdote du brochet et de la grenouille, E. Jovy en découvrit la source dans le livre de Dubravius, De piscinis et piscium qui in eis aluntur..., dont la première édition que nous ayons découverte date de $1559^{4}$. Jovy cite l'anecdote pertinente, qui fut reprise dans un livre de Johann Rudolf Camerer (pseudonyme: Camerarius), intitulé : Sylloges memorabilium medecinœ, et mirabilium naturœe arcanorum centuriœ duodecim (Argentorati 1626-30). Jovy soutient alors que le livre de Camerer devint sans doute un manuel de traduction latine dans les écoles, les collèges et les universités, sans apporter d'autre preuve de cette conjecture que l'emprunt de cette même anecdote dans un manuel latin de l'année 1836. Dans l'article de Jovy, on comprend mal pourquoi le duc de Liancourt aurait emprunté cette anecdote à Camerer, plutôt que directement à Dubravius : les deux auteurs sont apparemment peu connus en France au XVII ${ }^{\mathrm{e}}$ siècle et rien ne nous permet d'assurer que le duc de Liancourt ait connu l'un ou l'autre de ces savants traités.

4 Nous n'avons pas trouvé de traduction française du livre de Dubravius, mais une traduction anglaise parut en 1659 sous le titre : A new book of good husbandry, very pleasant and of great profit, both for gentlemen and yeomen, containing the order and manner of making fish-ponds, etc. (London, 1599). Cette traduction eut apparemment un certain succès: Dubravius est cité par Robert Burton dans son Anatomy of melancholy $(1621)^{5}$ et il est fréquemment invoqué comme source par Izaac Walton dans son traité célèbre: The Compleat Angler, or the contemplative man's recreation. Being a discourse of rivers, and fishponds, and fish, and fishing. Not unworthy theperusal of most anglers. Publié pour la première fois en 1653, le traité d'Izaac Walton eu un succès immense et immédiat : quatre éditions nouvelles parurent avant la mort de l'auteur en $1683^{6}$. La deuxième édition fut " considérablement augmentée » et c'est dans cette édition que parut pour la première fois l'anecdote suivante :

But before I proceed further, I am to tell you, that there is a great antipathy betwixt the pike and some frogs : and this may appear tot the reader of Dubravius, a bishop in Bohemia, who, in his book of Fish and Fishponds, relates what he saw with his own eyes, and could not forbear to tell the reader.Which was :

"As he and bishop Thurzo were walking by a large pond in Bohemia, they saw a frog, when the pike lay very sleepily and quiet by the shore side, leap upon his head; and the frog having expressed malice or anger by his swoln cheeks and staring eyes, did stretchout his legs and embrace thepike'shead, and presently reached them to his eyes, tearing with them, and his teeth, those tender parts : the pike moved with anguish, moves up and down the water and rubs himself against weeds, and whatever he thought might quit him of his enemy; but all in vain, for the frog did continue to ride triumphantly, and to bite and torment the pike till his strength failed; and then the frog sunk with the pike to the bottom of the water: then presently the frog appeared again at the top, and croaked, and seemed to rejoice like a conqueror, after which he presently retired to his secret hole. The bishop, that had beheld the battle, called his fisherman to fetch his nets, and by all means to get the pike that they might declare what had happened: and the pike was drawn forth, and both his eyes eaten out; at which when they began to wonder, the fisherman wished them to forbear, and assured them he was certain that pikes were often so served ». I told this, which is to be read in the sixth chapter of the book of Dubravius, unto a friend, who replied, "It was as improbable as to have the mouse scratch out the cat's eyes ". But he did not consider, that there be Fishing frogs, which the Dalmatians call the Water-devil, of which I might tell you as wonderful a story. ${ }^{7}$

[Traduction: Mais avant que d'aller plus loin, il faut que je vous dise qu'il y a une grande antipathie entre le brochet et certaines grenouilles : c'est ce qu'apprend le 
lecteur de Dubravius, évêque de Bohème, qui, dans son livre Des Poissons et des Étangs , fait part de ce qu'il a vu de ses propres yeux et qu'il n'a pas pu s'empêcher de raconter au lecteur. Voilà l'histoire :

"Alors que lui et l'évêque Thurzo se promenaient au bord d'un étang en Bohème, ils virent une grenouille sauter sur la tête d'un brochet pendant que celui-ci se reposait tranquillement près du rivage; les joues enflées et les yeux hagards de la grenouille exprimaient son agressivité ou sacolère, et elle étendit ses pattes pour entourer la tête du brochet; peu après elle atteignit les yeux qu'elle creva avec les pattes et avec les dents ; torturé de douleur, le brochet se précipitait ici et là dans l'étang, se frottant contre les herbes et contre tout ce qui pouvait lui permettre de se débarrasser de son adversaire; mais en vain, car la grenouille continuait à chevaucher triomphalement, et à mordre et à torturer le brochet jusqu'à ce qu'il n'ait plus de force; et alors la grenouille plongea avec le brochet au fond de l'eau ; peu après elle reparut, et croassa, et semblait se réjouir comme un conquérant, après quoi elle se retira dans sa cachette. L'évêque, qui avait suivi le duel, ordonna à son pêcheur de prendre ses filets et de faire de son mieux pour récupérer le brochet pour qu'ils puissent faire le récit de cet événement; on retira alors le brochet de l'eau, et ses deux yeux avaient été arrachés; et alors qu'ils commençaient à s'en étonner, le pêcheur les interrompit pour les assurer que les brochets rencontrent souvent une telle mort".

J'ai raconté cette histoire, qui se trouve au sixième chapitre du livre de Dubravius, à un ami, qui m'a répondu : "C'est aussi vraisemblable que de voir la souris crever les yeux au chat. " Mais il n'a pas réfléchi qu'il existe des grenouilles-pêcheuses, que les Dalmatiens appellent diableresses, dont je pourrais vous raconter une histoire tout aussi extraordinaire ...]

5 Nous n'avons pas trouvé d'indice permettant de croire que le duc de Liancourt ait connu le texte d'Izaac Walton. Toutefois, le fragment de Pascal fait partie de la Série XXVI, composée probablement entre le mois de mai et septembre $1660^{8}$, alors que The Compleat Angler connaissait un très grand succès; à cette époque diverses expériences sur les animaux furent réalisées à Vaumurier et les amis de Port-Royal accordaient un certain intérêt à la doctrine de l'automatisme animal, comme vous l'a indiqué Nicolas Fontaine ; d'autre textes, dans le Recueil de choses diverses ${ }^{9}$, permettent de croire que les amis du duc de Liancourt s'intéressaient à l'automatisme animal et à la philosophie anglaise ; enfin, à cette même époque de nombreux voyageurs anglais visitèrent Port-Royal, où furent chaleureusement accueillis les Royalistes en exil au moment de la Guerre Civile ${ }^{10}$. Ensemble, ces indices permettent de croire que la remarque de Pascal porte, non pas sur les textes obscurs de Dubravius et de Camerer, mais plutôt sur la version de cette anecdote qu'on lisait dans Je traité célèbre d'Izaac Walton.

\section{NOTES}

1. E. Jovy, Études pascaliennes, IV : Investigations péripascaliennes, Paris, 1928, pp. 58-66.

2. N. Fontaine, Mémoires pour servir à l'histoire de Port-Royal, Utrecht 1736, II, p. 470.

3. Pascal, Cuvres complètes, éd. J. Mesnard, I, p. 1105. 
4. J. Dubravius, De piscinis et piscium qui in eis aluntur naturis libri quinque... (Impressum in oppido Moraviae Prostanna, in officina J. Guntheri, 1559, 8e). Ré-éditions en 1596, 1623, 1671. L'édition de 1596 est l'œuvre de Ludwig Joachim Kammermeister (pseudonyme : Camerarius).

5. Robert Burton, The Anatomy of melancholy, éd. H.T. Jackson, New-York, 1977, II, p. 25, 73 : Partie I, section II, Mem. I, sous-section I, et Partie II, Section II, Mem. IV.

6. Ré-éditions en $1655,1661,1668$ et 1676 . La première traduction française est celle de Charles de Massas, Manuel du pêcheur à la mouche artificielle et du pêcheur à toutes lignes, Paris, 1852.

7. Izaac Walton, The Compleat Angler..., The second edition much enlarged, Printed by T. M[axey] for Rich. Marriot and to be sold at his shop in St. Dunstan's Churchyard, Fleetstreet, London, 1655, p. 200.

8. Voir J. Mesnard, Les Pensées de Pascal, Paris, 1976, pp. 44-45.

9. B.N. n.a.f.4333 : Voir le commentaire de J. Orcibal, « Descartes et sa philosophie jugés à l'Hôtel Liancourt ", Descartes et le cartésianime hollandais, Paris, Amsterdam, 1950, pp. 91, 94-98, n. 36 et 37; voir aussi la récente édition critique du Recueil établie par J. Lesaulnier, thèse dactylographiée, Sorbonne Paris IV, 1990.

10. R. Clark, Strangers and sojourners at Port-Royal, Cambridge, 1932, chap. III-IV. Izaac Wallon était lui-même Royaliste, mais nous n'avons pas trouvé de trace d'un voyage en France par un de ses amis à cette époque. Izaac Walton «le jeune" devait voyager en France avec l'évêque Ken, éminent sympathisant de Port-Royal, en 1675 (ibid., p. 138).

\section{AUTEUR}

\section{ANTONY MCKENNA}

Professeur de littérature française

Université de Saint-Étienne, Institut d'histoire de la pensée classique (CNRS UMR 5037) 